\title{
Aurelio Peccei: Industrialist, Humanist and Quality of Life Scholar (1908-1984)
}

\author{
Richard J. Estes ${ }^{1}$
}

Published online: 17 February 2017

(C) Springer Science+Business Media Dordrecht and The International Society for Quality-of-Life Studies (ISQOLS) 2017

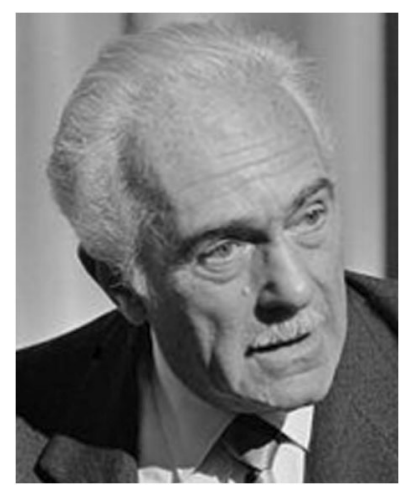

Aurelio Peccei was an Italian industrialist and scholar who is best known as the founder and first president of the Club of Rome - an organization which raised considerable international attention in 1972 with its report on The Limits to Growth (1972). Peccei was born in Turin, Italy, July 4, 1908. He spent his youth there, eventually graduating from the University of Turin with a degree in economics in 1930. Soon thereafter he went to the Sorbonne in Paris with a scholarship and was awarded a free trip to the former Soviet Union. Peccei's knowledge of other languages brought him to Fiat S.p.A., a major manufacture of Italian automobiles and other automotive equipment. Although under continued suspicion as an anti-fascist in the early 1930s, in 1935 a successful mission by Peccei for Fiat in China established his position in Fiat management. During World War II, Peccei became involved in the anti-

Richard J. Estes

restes@sp2.upenn.edu

1 School of Social Policy \& Practice, University of Pennsylvania, Philadelphia, PA, USA 
fascist movement and in the resistance, where he was a member of the "Giustizia e Libertà".

In 1964, Peccei was asked to become President of the Italian business machine firm Olivetti. Olivetti was facing significant difficulties at that time due to the technological advances occurring in the office machine sector. Peccei, with his foresight and his entrepreneurial talent, was able to turn the situation at Olivetti around and helped the company regain its position as a leading European business and supplier of office machinery. Peccei went on to give leadership to a wide range of still other firms and corporations. These experiences gave him tremendous insights into the nature of the social, political, economic, and technological challenges that confronted societies worldwide at the end of the second world war. Peccei summarized these insights into four highly acclaimed books: The Chasm Ahead, Macmillan, NY (1969); The Human Quality, Pergamon Press (1977); One Hundred Pages for the Future, Pergamon Press (1981); and, Before it is Too Late: A Dialogue with Daisaku Ikeda, I.B. Tauris (2008).

Beyond his own scholarship, Peccei is known for his support that lead to the founding of the highly influential, mostly European based, think tank, the Club of Rome (http://www.clubofrome.org/). The Club of Rome selected some of the best scholars of the time and both alone and with the help of governments and other nongovernmental organizations, went on to produce a series of monographs that had a profound impact on worldwide dialogue concerning both near- and long-term prospects for the planet. In particular, outcomes associated with uncontrolled population growth, over-exploitation of the planet's dwindling natural resources and high levels of environmental degradation. Among the most important of the earliest social indicator and social modeling reports issued by the Club of Rome included: The Limits to Growth (1972): Donella H. Meadows, Dennis L. Meadows, Jørgen Randers, and William W. Behrens III; Mankind at the Turning Point (1975): Mihajlo D. Mesarović, Eduard Pestel; and, Reshaping the International Order (1976): Jan. Tinbergen. Future entries in the Pioneers section will highlight the work of many of these additional pioneers in applied quality of life research field.

The Club of Rome continues to be active today and has continued its legacy of commissioning high profile reports in virtual all areas of social, physical, and environment sciences (Masini 2004). None of these highly influential contributions to the fields of social indicators, social reporting, and applied quality of life research would have occurred without the remarkable leadership of Aurelio Peccei, one of the century's most influential wellbeing scholars and promoters. Peccei died in Rome on March 14, 1984.

\section{References}

Masini, E. B. (2004). The Legacy of Aurelio Peccei Twenty Years after his Passing and the Continuing Relevance of his Anticipatory Vision, Rome, November 23. https://web.archive.org/web/20080517044645 /http://www.clubofrome.org/archive/publications/AURELIO_PECCEI_-_MASINI_LECTURE.pdf. 